\title{
Bankar og fjármálamarkaðir
}

\author{
Guðrún Johnsen ${ }^{1}$
}

\begin{abstract}
Ágrip
Eftir íslenska bankahrunið pykir ljóst að meginstoðir fjármála- og efnahagskerfisins voru á veikum grunni reistar. Stofnanir jafnt sem einstaklingar brugðust og kerfið í heild stóðst ekki pær kröfur sem gerðar voru til pess. Hér verður farið yfir hverjir eru haghafar bankakerfisins sem knúðir eru áfram af ólíkum hagsmunum og hvötum. Pá er spurt hvaða veikleika megi finna meðal peirra meginhvata sem eru byggingarefni hins íslenska efnahags- og fjármálakerfis. Niðurstaðan er sú að brotalamir má finna á öllum helstu stoðum kerfisins sem fjárfestar reiða sig á, svo sem í dómskerfi, skilvirkni markaða, hvatakerfum bankastofnana, og stjórnarháttum fyrirtækja. Valdhafar landsins verða að lagfæra pessar brotalamir hið fyrsta svo að íslenskt efnahagslíf og íslenskur fjármálamarkaður geti talist frjór jarðvegur fyrir fjárfesta að yrkja.
\end{abstract}

\begin{abstract}
In the aftermath of the failure of the Icelandic financial sector, embedded flaws of all the main pillars of the Icelandic economic system became evident. Individuals and institutions alike failed so that the system itself did not deliver the outcome it was set to do. This article presents a survey of the main stakeholders of the financial system and maps out the incentive structure which defines the system and its outcome. The main conclusion is that the institutional structure of Iceland needs significant repairs so that Iceland can be considered favourable place for investments. The main weaknesses identified by this paper lie in the judicial system, given the lack of specialization among judges, as well as classaction suits being illegal; the low turnover and small size of the stock market; and a weak governance structure of firms. Incentive schemes of the fallen Icelandic banks proved also to be highly flawed in terms of protecting the interests of the minority shareholder.
\end{abstract}

JEL flokkun: L51

Lykilhugtök: Hvatakerfi, stofnannauppbygging, fjármálastofnanir, fjármálastöđugleiki.

\footnotetext{
${ }^{1}$ Pátttakendur á ráðstefnunni Atvinnulif við nýjar aðstaður í júní 2010 eiga pakkir skyldar fyrir góðar spurningar. Áslaug Björgvinsdóttir, Gylfi Zoega, Jón Pór Sturluson, Kristín Haraldsdóttir og Pórarinn R. Einarsson eiga sömuleiðis pakkir mínar skyldar fyrir gagnlegar ábendingar, innblástur og yfirlestur, sem og nafnlaus ritrýnir Tímarits um viðskipti og efnahagsmál. Rangfærslur, ef einhverjar eru, eru alfarið á mína ábyrgð.
} 


\section{Inngangur}

Eftir uppgjör rannsóknarnefndar Alpingis pykir mörgum sýnt að helstu leiðtogar viðskiptalífsins, og sérstaklega bankakerfisins, hafi í besta falli brugðist og kunni í versta falli að vera sekir um lögbrot. Fyrir utan brot á bókhaldslögum og umboðssvik, sem til umfjöllunar voru í Hafsskipsmálinu svokallaða og Baugsmálinu, eru Íslendingar fyrst núna í návígi við hneykslismál viðskiptalífsins (e. business scandals) ${ }^{2}$ sem próaðri markaðir hafa fjallað um í áratugi, jafnvel hundruð ára pegar litið er aftur til bandarísku auðjöfranna (e. robber-barons) sem komu sér fyrir á öndverðri 20. öld.

Hönnun á kerfi er slök hér; stofnanaumhverfi, lagaramminn, eftirfylgni með lögum og reglum, sem einkum leiðir til pess að einstaklingar, bona fide, valda öðrum tjóni pegar peir leitast við að hámarka eigin hag eða vinnuveitenda sinna. Рað er pví brýnt að Íslendingar leggi áherslu á að bæta sem fyrst pað kerfi sem brást svo koma megi í veg fyrir að atburðir af peirri stærðargráðu sem íslenska efnahagshrunið árið 2008 var, hendi aftur. Búa parf til kerfi sem stuðlar að skilvirkni og hagsæld, par sem hvatar og styrkingarskilmálar kerfisins fá hagræna leikendur til að leita góðrar útkomu fyrir sjálfa sig sem og kerfið í heild sinni.

Hönnun bankakerfa er vandasöm vegna hás flækjustigs starfseminnar. Hún á rætur sínar að rekja til pess að haghafar sem koma að rekstri banka eiga afar ólíkra hagsmuna að gæta. Hluti af hinu vandasama verki er að halda úti öflugu eftirliti og gæta pess að andi laganna og vilji löggjafans nái fram að ganga í peim efnum sem verða illa greypt í stein lagaákvæðanna.

Hér verður tekin til umfjöllunar starfsemi banka og fjármálamarkaða og hvernig við skipuleggjum hana pannig að hún veiti rekstraraðilum og fjárfestum í íslensku atvinnulífi rétta hvata til að auka atvinnu, skatttekjur, gjaldeyristekjur og almenna hagsæld í landinu.

Pegar skoðað er hvernig bankakerfi skuli uppbyggð parf fyrst að huga að hagsmunum ólíkra haghafa, hvaða áhrif fyrirliggjandi hvatakerfi (e. incentive structure) hefur á pá og hvað peir ætla með hlutdeild sína í bankakerfinu. Hér verður lögð fram kortlagning á peim hvötum sem drífa helstu haghafa bankakerfisins áfram. Bent er á helstu brotalamir á skilvirkni pess hvatakerfis sem er til staðar í íslensku viðskiptalífi en einnig lagðar fram tillögur til að hefja umræðu sem leiðir til lausna á peim vandamálum.

Fjallað verður um pað hvernig á að binda ólíka hagsmuni saman - og hvernig ólík uppbygging bankastofnana á við til að öllu áhætturófinu sé sinnt, p.e. að áhættusæknir fjárfestar geti komið fjármunum sínum í vinnu. Pá verður fjallað um hvernig stemma má stigu við pví að áhættufælnum fjárfestum, svo sem innstæðueigendum, sé misboðið með áhættusækni hluthafa bankastofnana sem fá peninga peirra að láni.

Sökum fámennis er aðsteðjandi hætta af sampjöppun eignarhalds fyrirtækja á Íslandi og neikvæðum áhrifum hennar á samkeppni. Pá stafar ekki síður kerfislæg ógn af sampjöppun skulda. Í ljósi peirrar sérstöðu er hér byrjað á að leggja fram tillögu um að farið verði að hætti t.d. Spánverja og komið upp skuldaskráningu, rétt eins og fyrirtækjaskráningu eða verðbréfaskráningu. Petta myndi gera hagstjórn og ákvarðanatöku lánastofnana upplýstari og par með skilvirkari, með miðlægri söfnun upplýsinga um skuldastöðu einstaklinga og lögaðila. Vísir að pessu hefur pegar verið innleiddur í lög með 10. gr. laga nr. 75/2010 sem

2 Hér er vísað til pýðingar á enska orðinu scandal, p.e. pegar einstaklingar hafa farið gegn siðferðisgildum samfélagsins sem leiðir til pess að orðstýr peirra skaðast eða tapast (e. loss of or damage to reputation caused by actual or apparent violation of morality or propriety). 
kveður á um mánaðarlega uppfærslu og afhendingu gagnaskrár fjármálafyrirtækja til Fjármálaeftirlitsins yfir skuldara sem skulda viðkomandi fjármálafyrirtæki yfir 300 milljónir ISK.

Pá er lagt til að skattur verði lagður á fyrirtækjasamsteypur svo koma megi í veg fyrir viðskiptablokkamyndun og falið eignarhald.

Einnig verður fjallað um æskilega launauppbyggingu bankamanna og forstjóra fjármálafyrirtækja sem leið til að stemma stigu við eða draga úr áhættufælni peirra, eftir pví sem við á. Hlutverk og efling stjórna hlutafélaga verður til umfjöllunar sem og gagnsemi hóplögsókna. Pá er bent á brotalamir á hinu íslenska dómskerfi sem og mikilvægi pess að endurreisa hér hlutabréfa- og skuldabréfamarkað.

\section{Hagsmunir haghafa bankakerfisins - ólík áhættusækni}

Ólík áhættusækni haghafa bankakerfisins er meginorsök pess flækjustigs sem einkennir uppbyggingu bankakerfa. Sé um kerfismikilvægan banka að ræða eru haghafar bankans mun fleiri, p.e. hagkerfið í heild sinni. ${ }^{3}$ Áhættusæknastir eru hluthafar bankans og er ávöxtunarkrafa peirra pví hæst og takmarkast aðeins við auknar líkur á að illa fari í rekstrinum. Hluthafar hafa ríka ástæðu til að ýta við áhættufælnum stjórnendum ${ }^{4}$ og fá pá til að taka pá áhættu sem parf til að uppfylla ávöxtunarkröfuna. Eftirlit hluthafanna á sér fyrst og fremst stað í gegnum hluthafafund, stjórn félagsins, innri og ytri endurskoðun og eftirfylgni með peim skilyrðum sem sett eru fyrir hvatalaunum.

Áhættusækni fjárfesta í skuldabréfum bankans er misjafnt farið. Peir koma að rekstri félagsins á ólíkum tímum, í ólíku efnahagsástandi og par með er samsetning fjárfesta sem kemur að rekstrinum breytileg. Eftirlit skuldabréfaeigenda með bankanum fer fyrst og fremst fram í gegnum lánasamninga eða eftirfylgni með sérstökum skilyrðum skuldabréfaútgáfunnar (e. covenants) sem og í gegnum verðlagningu skuldatryggingamarkaðarins, sé hann fyrir hendi.

Innstæðueigendur og hluthafar eru hvorir sínum megin á áhættuskalanum. Innstæður ættu alla jafna að vera ódýrasta fjármögnun sem bönkum stendur til boða. Innstæðueigendur eru afar ósamstæður hópur og samtakamáttur peirra í eftirliti er enginn. Innstæðutryggingarsjóður er sá aðili sem með réttu ætti að halda úti eftirliti fyrir hönd innstæðueigenda enda hefur hann einna ríkastan (fjárhagslegan) hvata til eftirlits með rekstri banka, ásamt lánveitanda til prautarvara og peim tryggingarfélögum öðrum sem selja skuldatryggingar. Í aðdraganda hruns íslensku bankanna mátti sjá að skuldatryggingaraðilar spáðu hvað gleggst fyrir um prot peirra. Pá bera endurskoðendur vissulega ábyrgð á pví að hafa staðfest að ársreikningar sýni glögga mynd af rekstri bankanna - en hér verður látið hjá

${ }^{3}$ Skilgreining á kerfislegu mikilvægi bankastofnana felst í aðstöðu peirra og víðtækum tengslum peirra við hagkerfið í heild. Ef pær falla eru allmiklar líkur til pess að pær taki margar aðrar fjármálastofnanir með sér í fallinu - við mat á pessu er horft til smitáhrifa, sampjöppunar, samfylgni eignasafna, samtíðina (e. condition) ásamt stærð stofnunarinnar. Sjá m.a. Thomson, (2009).

4 Jensen \& Meckling (1976), bls. 353. Peir telja áhættufælni stjórnenda leiða til tjóns hluthafa. Til að draga úr pví sé rétt að byggja upp sömu áhættusækni hjá stjórnendum með pví að hluti launa peirra felist í hlutabréfaeign í fyrirtækinu sem peir vinna hjá eða afleiðum peirra. Jensen \& Murphy (1990) lýsa áhættufælni stjórnenda frekar. Önnur líkön gera ráð fyrir áhættuhlutleysi stjórnenda, svo sem Williamsson (1988) og Hart (1988). 


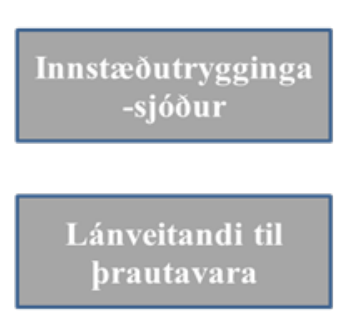

Eftirlit með fjárhagslegum skuldbindingum við eftirlitsskyldaaðila

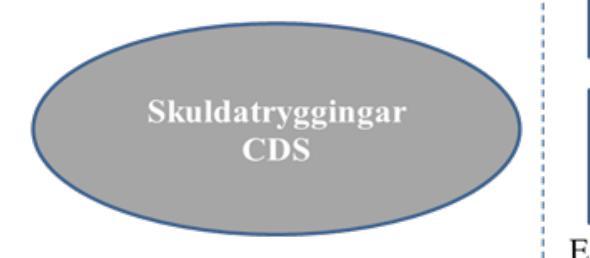

Eftirlit án fjárhagslegrar íhlutunar

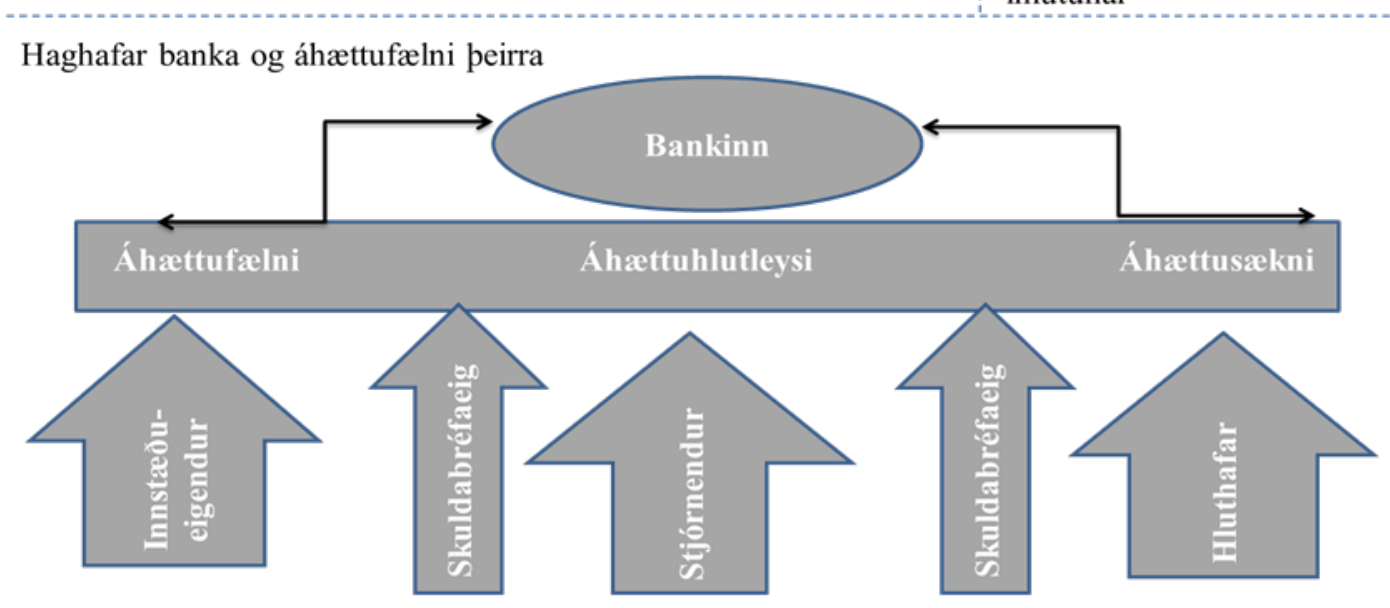

Mynd 1. Haghafar og eftirlitsaðilar bankakerfisins

líða að leggja mat á hversu skilvirkt pað eftirlit var fyrir fall íslensku bankanna. Öðrum eftirlitspáttum bankanna verður pó gefinn frekari gaumur.

\section{Styrkingarskilmálar - hvað hefur áhrif á hegðun stjórnenda?}

Hefðbundnar kenningar hagfræðinnar um vandamál eigandans og erindreka hans (e. principal-agent problem $)^{5}$ gera ráð fyrir að erindrekinn sé með öllu ónæmur gagnvart áhættu par sem hann tekur að sér umboðsmennsku og ávaxtar fé annarra en ekki sitt eigið. Erindrekinn, eða stjórnandinn, er launamaður og hann er bundinn af tilteknum hliðarskilyrðum pegar hann tekur ákvörðun um hvort hann telur sig geta tekið að sér viðkomandi starf og hvernig (e. participation constraint). ${ }^{6}$

Áhættufælni stjórnandans veldur pví að eigandi fyrirtækisins verður, eftir pví sem tilefni og hugur hluthafanna stendur til, að setja honum skorður eða hvetja hann áfram með fyrirmælum og starfsskilyrðum, hvatagreiðslum eða fríðindum einhvers konar sem stjórnandinn ávinnur sér pegar fyrirframskilgreindu markmiði er náð. Aðrir styrkingarskilmálar (e. incentive structure, re-enforces) sem stjórnandinn gengst undir pegar hann tekur við starfi felast í peirri samkeppni sem ríkir milli fyrirtækja á markaði hans, hættu á lögsóknum vegna meintra brota á lögum eða tjóni sem hluthafar kunna að verða fyrir vegna

${ }^{5}$ Sjá m.a. Handbook of New Institutional Economics, 2005, Springer Hollandi.

6 Pá er kenningagrunnur um vandamál eigandans og erindrekans víður og ber að nefna að kannað hefur verið hvaða áhrif ólík áhættufælni erindrekans og eigandans hefur á ákvarðanatöku. Pó að áhættuhlutleysi stjórnandans megi teljast grunnforsenda pá eykst pörf fyrir árangurstengingu launa eftir pví sem áhættufælni stjórnandans er meiri, sjá m.a. Grossman og Hart (1983), Laffont og Matrimont (2001). 
starfa hans. Pá er mikilvægt pað eftirlit sem eigandinn eða stjórnir fyrirtækjanna halda úti gagnvart stjórnandanum og almennum stjórnarháttum fyrirtækisins (e. corporate governance), einnig annars konar eftirlit sem bankastjórnendur gangast undir, svo sem opinbert fjármálaeftirlit. Sjá myndræna framsetningu á pessum páttum á mynd 2.

Séu pessir helstu styrkingarskilmálar hafðir í huga sitja íslenskir fjárfestar ekki við sama borð og fjárfestar á alpjóðamörkuðum og ber par að nefna eftirfarandi pætti sérstaklega.

\section{Starfshættir - Eftirlit (e. Governance)}

\subsection{Hlutverk og skilvirkni stjórna}

Prátt fyrir að rannsóknir hafi ekki verið gerðar á Íslandi um starfsemi stjórna íslenskra hlutafélaga, fyrir utan umfjöllun Rannsóknarnefndar Alpingis (RNA) og viðauka skýrslu RNA um siðferði, bendir margt til pess að starfsemi stjórna sé ekki fullmótuð að efni og innihaldi pó að formi sé fylgt.

Umfjöllun RNA um starfsemi íslensku bankanna fyrir hrun er samfelldur áfellisdómur yfir stjórnum bankanna - pó að skýrslunni láist að fjalla um pað sérstaklega ef undanskilin er umfjöllun siðfræðihópsins í viðauka skýrslunnar. Af peirri umfjöllun að dæma einkenndust störf íslensku bankastjórnanna af undirgefni við stjórnendur og skorti á eftirfylgni með gerðum samningum. ${ }^{7}$ Stjórnirnar létu óátalda augljósa sjálftöku, svo sem í tilfelli reksturs útibús Kauppings í Bretlandi, óhóflegra bónusgreiðslna sem ákveðnar voru út frá geðpótta8 og útgáfu falsks hlutafjár sem fjármagnað var af bönkunum sjálfum í gegnum skúffufyrirtæki (e. Special Purpose Vehicle). ${ }^{9}$ Almennt pekkingarleysi einkenndi störf stjórnanna eins og lýst er í skýrslunni. Til vitnis um pað ber hæst tilhæfulausar varnir útgefinna kaupréttarsamninga hjá Landsbankanum með kaupum á eigin bréfum á markaði í gegnum aflandsfélög og áhrif slíkra kaupa á markaðsverð bréfa félagsins; lánveiting til starfsmanna vegna hlutafjárkaupa í tilfelli Glitnis og Kauppings (samanlagður eignarhlutur starfsmanna skyldi vera $9 \%$ af útistandandi bréfum Kauppings) á fáheyrðum lánskjörum sem á stundum voru betri en bankans sjálfs; samningsbrot gagnvart starfsmönnum Glitnis pegar peim var neitað eða ekki hirt um að sinna veðköllum til að mæta skuldbindingum skv. lánasamningunum; áhrif pess tómlætis á hlutabréfaverð félaganna; og að lokum hið falska eigið fé sem búið var til í öllum bönkunum - en par brást eftirlitsskylda fyrrum stjórna bankanna algerlega.

Mannauður stjórnarmanna í fjármálafyrirtækjum parf að vera ríkur í ljósi flækjustigs bankastarfsemi í nútímahagkerfum. Slíkur mannauður er pví dýr. Minni hluthafar verða að passa upp á að óháðum mönnum sé komið fyrir í endurskoðunarnefndum og stjórnum til að auka líkur á góðum stjórnarháttum. Peir purfa einnig að krefjast pess að nægum fjármunum sé varið í starfsemi stjórnanna svo að til stjórnarstarfa veljist hæft fólk. Hár væntur kostnaður fylgir hættunni á lögsóknum á hendur hlutafélögum ef stjórn eða stjórnendur valda stórum eða smáum hluthöfum tjóni. Pví er forsvaranlegt að verja umtalsverðum fjármunum til að styrkja stjórnir og standa straum af peim kostnaði.

${ }_{7}$ Sjá m.a. umfjöllun RNA um samningagerð stjórnar Íslandsbanka, síðar Glitnis, við forstjóra félagsins bls. 37-42 í 3. bindi skýrslu RNA.

8 RNA sýnir fram á að engin tengsl voru milli árangurs einstakra rekstrardeilda og bónusgreiðslna til starfsmanna, bindi 3, kafli 10, bls. 102-103.

9 Sjá umfjöllun 10. kafla skýrslunnar um Hvatakerfi bankanna, bindi 3, en skv. henni sampykkti m.a. stjórn Landsbankans útgáfu nýs hlutafjár til að mæta skuldbindingum bankans vegna útgáfu kaupréttarsamninga sem voru keyptir af aflandsfélagi með fjármögnun frá priðja aðila og sjálfskuldarábyrgð Landsbankans. 


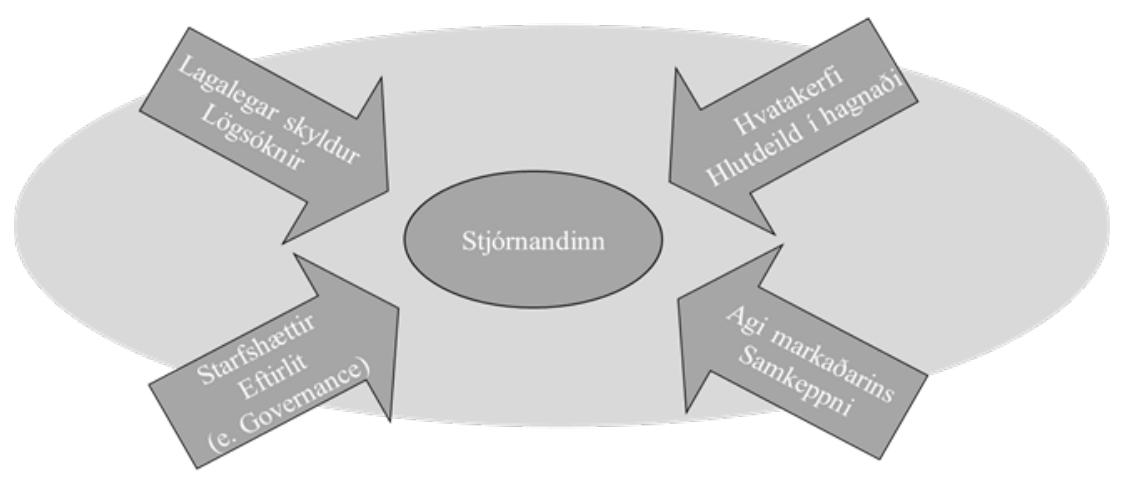

Mynd 2. Styrkingarskilmálar og pættir hvatakerfis til að aga stjórnandann

\subsection{Seðlabankinn - eftirlitsaðili kerfismikilvægra fjármálastofnana}

Í ljósi stöðu Seðlabankans sem lánveitanda til prautarvara parf að skerpa á hinu lögboðna hlutverki hans sem eftirlitsaðila með fjármálastöðugleika. Í pví felst að hann á að hafa valdheimildir til að skikka kerfismikilvægar stofnanir til að auka lausafé sitt og draga úr skuldsetningu, m.ö.o. að auka eiginfjárkröfur, selja eignir, auka veðkröfur útlána, breyta afskriftarframlagi, stýra lánaflokkun, setja skorður á sampjöppun útlána til einstakra atvinnugreina, herða kröfur um gjaldeyrisjöfnuð, setja fram kröfur um skorður á mismuni milli líftíma eigna og skulda (e. maturity mismatch) og breyta launauppbyggingu og hvatakerfi fjármálastofnunar, svo eitthvað sé nefnt, til að draga úr líkum á falli slíkrar stofnunar. Allt petta fellur pó, að mati höfundar, undir pau nauðsynlegu tæki sem Seðlabankinn hefur til umráða nú pegar í pví skyni að uppfylla lagalega skyldu sína um að tryggja fjármálastöðugleika. Peim hefur hins vegar ekki verið beitt fram að pessu. Sé lagaleg óvissa um hvort pessi úrræði séu til staðar parf að eyða henni sem fyrst. Pá kunna að vera uppi sjónarmið um hvort eftirlitsaðilinn skuli yfir höfuð hafa slíkar valdheimildir pó að pví áliti sé haldið á lofti hér að vegna hins mikla og víðtæka kostnaðar sem óstöðugleika eða fjármálakerfisáföllum fylgja ættu öll tæki að vera tiltæk peim stofnunum sem hafa á ábyrgð sinni að tryggja fjármálastöðugleika.

\subsection{Innstæðutryggingarsjóður}

Einn af peim eftirlitspáttum sem brugðust í hruninu var ábyrgur tryggingaraðili, p.e. innstæðutryggingarsjóður. Pví máli til stuðnings nægir að benda á pað hversu illa sjóðurinn var fjármagnaður og hversu litla tiltrú hann hafði hjá innstæðueigendum pegar heilbrigði bankastofnanna var dregið í efa. Pá má einnig benda á að innstæðutryggingarsjóður brást ekki við áhættusamri söfnun innlána íslenskra bankaútibúa í erlendri mynt á árunum 20062008. Sjá nánar umfjöllun um petta í skýrslu Rannsóknarnefndar Alpingis, kafla 17.

Раð er í raun erfitt að trúa að hér hafi verið rekinn tryggingarsjóður allt frá árinu 1999 sem innheimti hlutfallslega sama verð fyrir allar tryggingar, hvort sem pað var gagnvart Sparisjóði pingeyinga eða fjölpjóða risafyrirtækjum, svo sem Glitni, Kauppingi og Landsbanka $(0.15 \%$ af meðalinnstæðum innlánsstofnunar fyrra árs uns $1 \%$ af meðalinnstæðum væri uppsafnað í sjóði), en tók t.d. ekki tillit til vaxtar pessara innlána og skiptir par engu hvaðan sú regla átti uppruna sinn. ${ }^{10}$ Pá er fáheyrt að tryggingartaki geti

${ }^{10}$ Lög um innstæðutryggingar og tryggingakerfi fyrir fjárfesta nr. 98/1999. 
frestað iðgöldum og samt notið tryggingaverndar eins og tilfellið var með íslensku bankana. Augljóst er að banki sem farinn er á höfuðið greiðir illa iðgjöldin inní tryggingarsjóð eftir gjaldprot! ${ }^{11}$ Slíkt fyrirkomulag hefur vitaskuld engin varnaðaráhrif. Innstæðutryggingarsjóður parf að sinna verðlagningar- og eftirlitshlutverki sínu einsog önnur tryggingarfélög.

\section{$5 \quad$ Agi markaðarins}

Par sem íslensku bankarnir eru óskráð hlutafélög nýtur aga hlutabréfamarkaðarins ekki við sem stendur. Pó að eining sé meðal fræðimanna um jákvæð áhrif virks fjármálamarkaðar á hagsæld hafa menn ekki getað sýnt fram á pað að markaðsdrifið hagkerfi (e. market based economy) vaxi hraðar en banka- og lánadrifið hagkerfi (e. bank based). Pó er sýnt að til að stuðla að heilbrigðum hagvexti verður annað hvort, ef ekki hvort tveggja, að vera til staðar; virkur hlutabréfamarkaður og sterkir bankar. ${ }^{12}$ Par sem bankakerfið á undir högg að sækja hvað varðar fjármögnun er pví enn brýnna að hlutabréfa- og skuldabréfamarkaður nái að byggjast upp og eflast að nýju á Íslandi. Margt bendir til pess að skráning félaga á hlutabréfamarkað stuðli betur að efnahagslegum framförum en ef hagkerfið er drifið áfram af útlánum banka eingöngu, einkum vegna umboðsvanda sem felst í bönkunum sjálfum sem annars sæju um pað hlutverk að miðla fé milli fjármagnseigenda og rekstraraðila. ${ }^{13}$

Samhliða uppbyggingu hlutabréfamarkaðar purfa stjórnvöld að herða eftirlit með útlánum kerfismikilvægra banka og pví hlutfalli útlána bankanna sem tryggt er með veðum í hlutabréfum. Slíkt eftirlit getur komið í veg fyrir óskilvirka verðlagningu hlutabréfa, eða hlutabréfabólur, en við enduruppbyggingu markaðarins er nokkur hætta á slíku. Hvatakerfi skráðra fyrirtækja verða að hvetja til langtímahugsunar stjórnenda en ekki einungis til pess að menn einblíni á útkomu fjórðungsuppgjöra enda eru fjárfestar á hlutabréfamarkaði langtímafjárfestar.

Opinberir aðilar geta einnig í auknum mæli beitt sér fyrir stofnanalegri umgjörð utan um áhættufjárfestingar í kringum nýsköpun og skattaafslátt til að auka hvata til slíkra fjárfestinga. Aukið framlag í Nýsköpunarsjóð, Tæknipróunarsjóð og aðra slíka eru mjög til framdráttar fyrirtækjum á allra fyrstu stigum líftímakúrfunnar.

11 Í pví samhengi má benda á starfsemi og ítarlega löggjöf um Alríkistryggingarfélag innstæðueigenda í Bandaríkjunum (FDIC- Federal Depository Insurance Corporation) sem fyrirmynd að öflugum tryggingaraðila og annað fyrirkomulag, svo sem viðhaft er í Bretlandi, par sem ekki er greitt í sérstakan tryggingarsjóð - en slíkt byggir vitanlega á annarri hugmyndafræði en peirri að verðleggja áhættu á söfnun innstæðna sem hugsanlega ógn við fjármálastöðugleika og viðurlög við henni.

${ }^{12}$ Levine (2004).

13 Sjá m.a. Levine(1991), Levine(2005), Morck og Nakamura (1999) sem sýna fram á að bankalánadrifin hagkerfi kunna að draga úr nýsköpun og hagvexti par sem bankar hafa sterkan hvata til að lána varlegar en fjárfestar á hlutabréfamarkaði. Weinstein og Yafeh (1998) fundu pessari kenningu stuðning í Japan par sem fyrirtæki sem hafa mjög náin tengsl við „sterka bankann“ búa við betra aðgengi fjármagni og eru par af leiðandi ekki eins lausafjárpurfi og pau fyrirtæki sem ekki njóta sama aðgengis að sterkum banka. Pau sem hafa tengsl við sterka banka 1) halda úti íhaldsamri stefnu um hægan vöxt og vaxa ekki hraðar en pau fyrirtæki sem ekki hafa sterk tengsl við banka, 2) notast frekar við fjármagnsfreka ferla í framleiðslu sinni en tengslarýrari fyrirtækin og 3) sýna fram á minni hagnað, par sem hinir sterku bankar eru í betri stöðu til að draga til sín hluta af arðseminni vegna hins nána samstarfs peirra við fyrirtækin. 


\subsection{Skattaafsláttur til minni hluthafa - skattur á fyrirtækjasamsteypur}

Skattaafsláttur fyrri ríkisstjórna af hlutafjárkaupum almennings gaf góða raun í uppbyggingu hlutabréfamarkaðar hér á landi á tíunda áratugnum. Til að stuðla að slíkri próun ættu stjórnvöld að íhuga pann kost alvarlega.

Samhliða slíkum skattaafslætti ætti að leggja sérstakan skatt á hagnað fyrirtækjasamsteypa, eða arðgreiðslur hlutdeildarfélaga, til að koma í veg fyrir hringamyndanir og ógagnsætt eignarhald á skráðum hlutafélögum. að er sú viðleitni sem löggjafinn á að sýna til að bregðast við viðvarandi hættu og hinu alpjóðlega vandamáli að hluthafar sem fara með virka eignarhluti í hlutafélögum (oft voldugar fjölskyldur sem hafa safnað auði sínum kynslóð fram af kynslóð) nota bolabrögð sem felast í flóknu krosseignarhaldi og kröfum um ríkari meirihluta (e. super voting rights) til að auka völd sín í fyrirtækjum og bönkum. RNA sýnir fram á að slíkt hafi gerst hér á landi á árunum 2000-2008 og um pað er fjallað í Levine (2005), La Porta et al. (1999), Morck, Strangeland og Yeung (2000), Cleassens et al. (2002), Caprio, Laeven og Levine (2003) og á fleiri stöðum.

Morck, Wolfenzon og Yeung (2005) sýna með ýmsum hætti fram á að 1) hinar voldugu fjölskyldur færi vald sitt í viðskiptalífinu gjarnan yfir í pólitískan búning og 2) beiti áhrifum sínum á hinum pólitíska vettvangi til að móta löggjöf og stefnumörkun hins opinbera til að vernda fyrirtæki sín gegn áhrifum samkeppninnar og jafnvel til að styrkja (e. subsidize) starfsemi fyrirtækja sinna með fyrirgreiðslum; beinum eða óbeinum styrkjum. Sampjöppun eignarhalds bjagar ákvarðanatöku innan fyrirtækjanna sjálfra sem og stefnumörkun í heimalandi peirra. Hún dregur úr nýsköpun, eykur rentusókn en heldur aftur af hagvexti og hagsæld. $^{14}$

\section{Lagalegar skyldur - Lögsóknir}

\subsection{Hóplögsóknir ${ }^{15}$}

Litlir og dreifðir hagsmunir minni hluthafa draga úr líkum á pví að peir höfði mál gegn stjórn og stjórnendum hlutafélags pótt á peim hafi verið brotið og pótt sameiginlega eigi minni hluthafar stærstan hlut félagsins. Skortur á lagaheimildum í íslenskum rétti fyrir fleiri en einn aðila til að höfða sameiginlega mál gegn félagi eða stjórnendum pess leiðir til pess að stjórnarhættir íslenskra fyrirtækja verða fyrir vikið bágbornari en í sambærilegu félagaformi og fjárfestingartækifærum erlendis, svo sem í engilsaxneskum rétti. Stjórnandinn telur sig par af leiðandi aðeins skuldbundinn til pess að gæta hagsmuna stærri hluthafa eða sinna eigin ef félagið er í mjög dreifðri eignaraðild. Lítil sem engin hætta er á lögsókn

${ }^{14}$ Levine (2005). Einnig má sjá umfjöllun um galla bankadrifinna hagkerfa hjá Rajan og Zingales (2003); Wenger og Kaserer (1998) sem sýna fram á hversu voldugir bankamenn í raun eru par sem peir fara í reynd með stóran hluta atkvæða í ljósi fjármögnunar sinnar til starfseminnar; Black og Moersch (1998) sem sýna fram á að par sem bankamenn hámarka aðeins eigin hag kunni peir að ganga gegn hag annarra fjármögnunaraðila en peir hafa á stundum hvata til samráðs við fyrirtæki gegn öðrum bönkum (útiloka lántökur fyrirtækja frá öðrum fjármálastofnunum); pá sýna Morck, Stangeland og Yeung fram á að bankadrifin hagkerfi kunni að draga úr flæði upplýsinga um fyrirtækin og viðbrögð hagkerfisins við reykmerkjum markaðarins verða ekki eins skilvirk (e. market signals), sbr. Hoshim, Kashyap og Sharfstein (1991).

${ }^{15}$ Eftir flutning pess erindis, sem pessi grein byggir á, sampykkti Alpingi lög nr. 117/2010 sem heimila fleirum en einum einstaklingi að vera aðili að einkamáli. Röksemdafærslurnar sem hér eru lagðar fram um gagnsemi hóplögsókna eru pó látnar standa. 
minnihlutaeigenda íslenskra hlutafélaga og pví er fátt sem stöðvar stjórnandann í að ganga jafnvel á rétt peirra ef vilji er fyrir hendi. ${ }^{16}$ Pá má einnig endurskoða dómaframkvæmd skaða- og miskabóta pannig að varnaðaráhrif dóma náist fram og að sá sem veldur tjóni verði ekki jafnvel settur á eftir heldur verr.

\subsection{Aðstaða dómskerfisins til að takast á við málefni fjármálamarkaðar og hlutafélaga}

Spyrja má hvort íslenskir fjárfestar njóti tilhlýðilegrar réttarverndar og geti búist við sambærilegri meðhöndlun íslenskra dómsstóla á málefnum peirra og peir hefðu notið í fjölmennari samfélögum par sem dómarar og dómstólar eru sérhæfðir. Íslenskir dómstólar hafa ekki, svo eftir verði tekið, lagt sig eftir pví að sérhæfa dómara. Áhöld er uppi um pað hvort dómarar hafi pekkingu og pjálfun til að geta tekist á við lagalegar deilur sem spretta upp á vettvangi fjármálamarkaðar og hlutafélaga. Pjálfun peirra lögfræðinga sem eru atkvæðamestir í íslenskri lögfræðistétt nú á tímum virðist fyrst og fremst felast í pósitífri lögfræði sem leggur áherslu á lögskýringar lagatextans sjálfs og að hann beri uppi rétt pegnanna á meðan helstu hneykslismál í viðskiptalífi Bandaríkjanna hafa verið til lykta leidd á grundvelli meginreglna laga, ${ }^{17}$ svo sem um heilbrigða og sanngjarna viðskiptahætti og að ekki megi afvegaleiða viðskiptavini. •að er pví einkar mikilvægt að dómarar og lögmenn séu einnig pjálfaðir í viðfangsefni fjármálafræða en ekki bara formi og pví prönga og takmarkaða sviði sem lagaákvæðin sjálf eða löggjafinn geta spáð fyrir um að upp kunni að koma í síkvikum heimi fjármálamarkaða. Peir purfa að vera í stakk búnir til að geta metið hvað er eðlileg viðskiptavenja, heilbrigðir og sanngjarnir viðskiptahættir. Til pess parf sérfræðipekkingu á pví sviði.

Nýlegir dómar um ólögmæti gengistryggingar lána í íslenskum krónum og í reynd lög um vexti og verðtryggingu nr. 38/2001 bera pessum pekkingarskorti á hagrænu efni nokkurt vitni en slíkt er ekki til pess fallið að auka tiltrú fjárfesta á íslensku dómskerfi og par með efnahagskerfi. Komist Hæstiréttur að sömu niðurstöðu og peirri sem höfð hefur verið eftir fyrrverandi dómara réttarins, Magnúsi Thoroddsen, ${ }^{18}$ par sem hann gengur út frá pví að samningsvextir, japanskir, svissneskir eða evrópskir vextir, skuli gilda til grundvallar lánum í íslenskum krónum ef gengistrygging yrði dæmd ólögleg, er ljóst að hvorki innlendir né erlendir fjárfestar eiga von á góðu kjósi peir að taka áhættu í íslensku efnahagsumhverfi og

${ }^{16}$ Athyglisverð og ólík túlkun Héraðsdóms og Hæstaréttar í máli Vilhjálms Bjarnasonar gegn stjórn Glitnis banka er íhugunarefni hvað petta varðar.

17 Til að nefna dæmi um petta má benda á að ákærur SEC á hendur Madoff voru háðar m.a. á grundvelli greinar 206(1) og 206(2) svokallaðra Advisors Act frá 1940 par sem segir: „It shall be unlawful for any investment adviser, by use of the mails or any means or instrumentality of interstate commerce, directly or indirectly- (1) to employ any device, scheme, or artifice to defraud any client or prospective client; (2) to engage in any transaction, practice, or course of business which operates as a fraud or deceit upon any client or prospective client.“ (Breyting á leturgerð er höfundar). Pá var mál á hendur stjórnendum Worldcom byggt á lögum um verðbréfaviðskipti, Securities Exchange Act 1934, svohljóðandi grein 13(a): SEC. 13. (a): „Every issuer of a security registered pursuant to section 12 of this title shall file with the Commission, in accordance with such rules and regulations as the Commission may prescribe as necessary or appropriate for the proper protection of investors and to insure fair dealing in the security." Sjá nánar ákæru SEC gagnvart Madoff http://www.sec.gov/litigation/complaints/2008/comp-madoff121108.pdf, og gagnvart Worldcom http://www.sec.gov/litigation/complaints/complr17588.htm

18 Magnús Thoroddsen: „Nokkur orð um dóma Hæstaréttar Íslands um hin gengistryggðu lán,“ Morgunblaðið 8. Júlí 2010. 
lána hér fé með einum eða öðrum hætti. Pó að lagabókstafurinn, sem verður að lagfæra sbr. röksemdir sem hér fara á eftir, lýsi pví yfir að gengistrygging sem lánsform sé ólögmæt kemur pað í hlut dómarans að skera úr um pað hvernig samningnum skal breytt til löglegs forms. Gengistryggt lán í íslenskri mynt og erlent lán sem veitt er í erlendum gjaldmiðlum eru efnislega samskonar lán. Við upprunalega samningsgerð lánsins lýsa báðir aðilar vilja til að lúta erlendum vöxtum en ekki íslenskum. Samningsaðilar gera sér pví grein fyrir að vilji peir njóta vaxtakjara í erlendri mynt fylgir áhættan af hinni erlendu mynt óhjákvæmilega með í samningnum og lántakandinn gengst í kjölfarið undir að taka á sig sveiflur hinnar erlendu myntar gagnvart íslensku krónunni hafi hann ekki yfir að ráða eignum eða tekjustreymi í peirri mynt sem hann tekur lánið í. Lántakandinn skrifar í mörgum tilvikum undir yfirlýsingu pess efnis.

Gjaldmiðillinn og vextirnir sem honum fylgja eru órofa heild enda ákvarða vextirnir gengi gjaldmiðilsins að öðru óbreyttu. Afgreiðslumátinn er svo háður forminu eftir pví sem lántakinn kýs, p.e. hvort afhentar eru íslenskrar krónur eða erlend mynt. Раð kemur erlendum fjárfestum spánskt fyrir sjónir að viðskiptavenja, sem myndast hefur á ríflega áratug eða meira, skuli nú vera talin ólögleg. Dómstólar hafa ítrekað lýst aðila gjaldprota á grundvelli greiðslufalls á gengistryggðum lánum en taka nú ekki afstöðu til pess ásetnings sem lá að baki upprunalegri samningsgerð pegar formið er dæmt ólöglegt og ákvarðað er hvað skuli koma í staðinn. Vitanlega voru lánin veitt og tekin á grundvelli pess að samningsaðilar vildu hvorki lúta verðtryggingu íslenskra krónulána né pví háa vaxtastigi sem hér hefur verið viðvarandi undanfarinn áratug eða svo.

Pá hafa verið nokkrar vangaveltur uppi um hver vilji löggjafans hafi verið í pví efni að banna gengistryggingu lánanna. Bent hefur verið á að löggjafinn hafi par með viljað tryggja aukin viðskipti með íslensku krónuna og knýja fram afhendingu gjaldeyris fremur en íslenskrar krónu, svo sem ef gjaldeyrishöft ríki í landinu, að bankastofnanir taki pað ekki upp að lána íslenskar krónur í dulargervi haftagjaldeyris í gegnum gengistryggingu. Pví er til að svara að pó að ásetningur löggjafans hafi verið á pann veginn dugar bann við gengistryggingu ekki til að ná honum fram. Bankastofnanir sem ekki eiga gjaldeyri, p.e. hvorki erlendar eignir né erlendar skuldir, hafa hvorki hvata né svigrúm til að skekkja gjaldeyrisjöfnuð sinn með pessu móti og myndu ekki veita lán í erlendri mynt, hvorki í hreinu formi né í gegnum gengistryggingu eins og íslenskir fjárfestar finna vel fyrir um pessar mundir.

Раð er brýnt að löggjafinn fari yfir lög um vexti og verðtryggingu frá árinu 2001 og leiðrétti pann efnislega misskilning sem felst í lögunum. Pá skal bent á pað frelsi sem lögin veita til að verðtryggja eða binda íslenska lánasamninga við sveiflur erlendra hlutabréfavísitalna skv. 14. gr. laganna en pað gengur gegn hinni meintu meginreglu um að lánasamningar í íslenskum krónum skuli einvörðungu vera bundnir vísitölu neysluverðs. Раð kunna að vera uppi sjónarmið um pað að lögin eigi ekki að stuðla að peirri neytendavernd sem felst í pví að meina aðilum sem hvorki eiga eignir né hafa tekjur í erlendri mynt að taka lán í erlendri mynt pó að höfundur pessarar greinar hafi efasemdir um slíkt. Раð hefði betur verið sett fram skýrar í lögunum til að ganga gegn meginreglu um frelsi í samningum.

Hitt er svo annað mál hvað stjórnvöld hefðu átt að gera til að mæta peirri gífurlegu áhættu sem raungerðist í kerfinu vegna lánanna pegar bankakerfið féll í október 2008. Mörg rök hníga að pví að pau hefði átt að færa með neyðarlögum yfir í verðtryggð íslensk lán við kerfisfallið. Margt bendir til pess að hagstjórninni hefði par með verið velt yfir á dómstóla 
vegna hinnar miklu pólitísku áhættu sem felst í pví að umbreyta skuldum á neyðartímum með pessum hætti. Pað er pó efni í aðra grein.

Fyrir pann sem horfir á dómaframkvæmd með auga gestsins verður einnig að segjast að рað kemur spánskt fyrir sjónir að Hæstiréttur landsins purfi að úrskurða um mál einstaklinga, svo sem peirra sem hafa verið dæmdir gjaldprota af Héraðsdómi. •að er jafnvel óhugsandi að Hæstiréttur purfi að sinna pví að vísa slíkum málum frá. Hið mikla álag á dómskerfið sem nú er óumflýjanlegt kallar á að dómstigin verði fleiri, verkefni Hæstaréttar afmörkuð og meiri sérhæfing tekin upp meðal dómara á Íslandi til að tryggja skilvirka úrlausn réttarágreinings á afar sérhæfðum sviðum. Pá er umhugsunarefni hvort ekki purfi að koma upp sérstökum viðskiptadómstól, svo eitthvert nafn sé sett fram yfir pað fyrirbæri, sem tæki fyrir lagalegan ágreining á sviði fjármála, samkeppnismála og annarra viðskiptamála.

Til að efla pennan pátt styrkingarskilmála íslenskra stjórnenda eða umboðsmanna, sem hér eru til umfjöllunar, parf löggjafinn einnig að huga að orðfæri laganna svo að pau gefi rými fyrir dómgreind dómarans við mat á viðskiptavenju, til að tryggja heilbrigða viðskiptahætti. Pá purfa háskólar jafnhliða að huga að og endurskipuleggja innihald náms íslenskra lögfræðinga og fjármögnunaraðilar námsins að gera umbætur mögulegar.

\section{Hvatakerfi - hlutdeild í hagnaði}

Sé hinn ólíki smekkur haghafa banka fyrir áhættutöku hafður í huga, pá sérstaklega áhættusækni hluthafa og áhættufælni innstæðueigenda, er sýnt að hvatakerfi bankanna verður að taka mið af pví. Lág eiginfjárhlutföll bankastofnana setja hvatagreiðslum líka skorður, sér í lagi ef eftirlit er veikt. ${ }^{19}$ Pað eru pó ekki allir bankamenn seldir undir sama kerfi. Sumir bankamenn taka nær enga áhættu fyrir hönd bankans með eigið fé hans, svo sem miðlarar og peir sem starfa við eignastýringu fyrir hönd priðja aðila. Pau varnaðarorð sem hér eru höfð uppi eiga ekki við um pessa starfsmenn.

Á meðan bankarnir eru nær einvörðungu fjármagnaðir með innstæðum verður ekki séð að æskilegt sé að hvetja bankastarfsmenn áfram til áhættusækni. Slíkt er pó nauðsynlegt í pví efnahagsumhverfi sem ríkir í landinu tveimur árum eftir kerfishrun. Til að draga úr áhættufælni, sem kerfið parfnast, er sýnt að skilja parf að viðskiptabankastarfsemi og fjárfestingabankastarfsemi, a.m.k. út frá stjórnunarlegri uppbyggingu, og mynda sérstök félög utan um hvora starfsemi fyrir sig. Um leið pyrfti að herða reglur og eftirlit með lántökum milli dóttur- og móðurfélags. Slíkt kann að valda óhagræði upp að einhverju marki par sem lóðrétt sampætting viðskiptabanka og fjárfestingarbanka hefur augljós hagræðingaráhrif í starfsemi samsteypunnar í eðlilegu árferði. Рað er pví ljóst að áhættusækni bankastjórnenda getur ekki orðið sú sem íslenskt efnahagslíf parf á að halda vegna peirra hliðarskilyrða sem innstæður setja peim. Vænt ávöxtun samanlagðrar starfsemi bankanna er pess vegna dæmd til að vera lægri en ella. Einsog sakir standa er samsetning viðskiptabankastarfsemi og fjárfestingarstarfsemi pví gagnkvæmur dragbítur.

Atriði sem parf pó að hafa í huga pegar hvatakerfin eru hönnuð:20

- Pær fjármálastofnanir sem teygja sig út á áhættuskalann og setja inn hvatakerfi í pví skyni mega ekki verða kerfismikilvægar.

\footnotetext{
${ }^{19}$ John, Kose (2003).

${ }^{20}$ Sjá einnig Jensen, M.; K. Murphy og D. Wruck (2004).
} 
- Árangursmæling í formi hlutfalla, svo sem arðsemi eigin fjár, er varasöm og meiri líkur á pví að hún sé misnotuð en hreinar krónutölur, svo sem áætlaður hagnaður eða hagsauki (e. Economic Value Added) á næsta rekstrarári.

- Hvatakerfi purfa að vera byggð á árangursmælingu, sem aftur er byggð á áreiðanlegum upplýsingum. Slíkt kallar á betri upplýsingatækni sem stuðlar að upplýstum ákvarðanatökum og er pví líklegra til árangurs.

- Mikilvægt er að hluti bónusgreiðslna komi til útgreiðslu á nokkrum árum og sé afturkræfur ef árangur næst ekki eða reynist vera annar en metið var í upphafi (e. clawback clauses).

- Pak á bónusgreiðslur er æskilegt og dregur úr hvata til sviksamlegrar skýrslugjafar um rekstrarárangur. Bónusgreiðslur sem eru priðjungur heildarlauna koma til álita sem viðmið. Fari bónusgreiðslur yfir 50\% af heildarlaunum kann pað að leiða til pess að umboðsmaðurinn hætti að taka mið af grunnlaunum sínum í neyslu og hvetji til umboðssvika ef árangur er undir viðmiðum og væntingum.

- Línuleg árangursmæling er árangursríkust, p.e. tiltekinn bónus er greiddur frá fyrstu krónu. Varast skal tröppugang í bónusviðmiðum, svo sem enginn bónus ef $10 \%$ arðsemi eigin fjár næst ekki. Undir peim kringumstæðum myndi enginn banki skila af sér 9,9\% arðsemi.

- Eigendur banka, sér í lagi par sem viðskiptabankastarfsemi er meðal rekstrareininga, purfa að gefa sér hóflega ávöxtunarkröfu. ${ }^{21}$ Eðlilegur vöxtur kerfismikilvægs banka getur varla orðið mikið meiri en hagkerfisins í heild.

\section{Lokaorð}

Ári eftir fall bankanna voru formlega reistir nýir bankar á rústum hinna föllnu. Íslensk stjórnvöld, sem höfðu tekið bankana yfir að öllu leyti í hruninu, lögðu fram efnahagsreikninga nýrra banka sem byggðu að mestu á innlendum eignum hinna föllnu banka. Skilanefndir sem fulltrúar protabúanna, í samráði við fulltrúa kröfuhafa, yfirtóku stóran eignarhluta tveggja stærstu bankanna og ríkið, sökum krafna sinna í gegnum innstæðutryggingarsjóð, tók yfir Landsbankann að stærstum hluta. Pannig létu stjórnvöld í raun hjá líða að standa fyrir nauðsynlegri breytingu á stofnanauppbyggingu íslenska fjármálakerfisins sem hafði vaxið landi og pjóð yfir höfuð.

Byggðir á hinum gamla grunni eru hinir nýju bankar, Arion banki, Íslandsbanki og Landsbanki, pað sem kalla má allsherjarbankar (e. universal banks). Peir sinna hvoru tveggja; viðskiptabankastarfsemi sem og fjárfestingarstarfsemi. Með tilvísun í umræðu um áhætturóf viðskiptavina og hluthafa banka er ljóst að allsherjarbankar pjóna og njóta pjónustu fjárfesta á öllu áhætturófinu sem takast á við úrlausnarverkefni sem peir erfðu frá gömlu bönkunum en jafnframt ný verkefni. Slík tilhögun stendur efnahagsuppbyggingu landsins nokkuð fyrir prifum par sem kraftar bankamanna fara öðru fremur í að leiðrétta gömul mistök annarra en að skapa ný tækifæri. Peim er aukinheldur pröngur stakkur skorinn hvað varðar áhættutöku í tengslum við ný verkefni í ljósi peirrar miklu áhættu sem tengist umbreytingarverkefnunum og einsleitni fjármögnunar.

раð kemur að mestu í hlut einkaaðila, fjárfesta og eigenda nýju bankanna að endurbyggja fjármálamarkaðinn á Íslandi. Stjórnmálamenn og embættismenn geta pó ekki staðið á hliðarlínunni og látið hjá líða að laða fram umhverfi sem styður við efnahagsupp-

${ }^{21}$ Til viðmiðunar tuttugufölduðust gömlu bankarnir prír, samanlagt, á sjö árum. 
bygginguna en lykilatriði er að halda í pá fjárfesta sem fyrirfinnast í landinu og helst að laða að erlenda svo að uppbyggingin hér geti verið sem hröðust og öruggust - og byggð á eigin fé að stærri hluta en áður. Á peirri vegferð er mikilvægt að huga að peim styrkingarskilmálum og hvötum sem drífa áfram leiðtoga viðskiptalífsins og hér hefur verið fjallað um. Einnig parf að sníða pá pannig að hag heildarinnar verði borgið. Par verður sérstaklega að huga að uppbyggingu dómskerfisins, hlutverki Seðlabankans sem verndara fjármálastöðugleika og búa til hvata til uppbyggingar heilbrigðrar fjárfestingarstarfsemi.

\section{Heimildir}

Black, S.W. og Moersch, M. (1998). Financial structure, investment and economic growth in OECD countries. Competition and Convergence in Financial Markets: The German and Anglo-American Models, North-Holland, New York, 157-174.

Caprio, L. og Levine (2003). Governance and Bank Valuation. NBER Working Papers No.10158, National Bureau of Economic Research, Inc.

Claessens, S., Djankov, S., Fan, J. og Lang, L. (2002). Disentangling the Incentive and Entrenchment Effects of Large Shareholdings. Journal of Finance, 57, 2741-2771.

Xavier og Vives. (2000). Corporate Governance: Theoretical and Empirical Perspectives. Cambridge University Press.

Grossman og Hart, O. (1983). Implicit Contracts under Asymmetric Information, The Quarterly Journal of Economics, 98, 123-156.

Hart, O. (1988). Incomplete Contracts and the Theory of the Firm. Journal of Law, Economics, $\mathcal{E}$ Organization, 4(1), 119-139.

Hoshi, T., Kashyap, A. og Sharfstein, D. (1991). Corporate structure, liquidity, and investment: Evidence from Japanese panel data. Quarterly Journal of Economics 27, 33-60.

Jensen, M., Murphy, K. og D. Wruck. (2004). Remuneration: Where we've been, how we got here, what are the problems, and how to fix them. European Corporate Governance Institute, Finance Working Paper, 44.

Jensen og Murphy. (1990). Pay Performance \& Top Management Compensation. The Journal of Political Economy, 98( 2), 225-264.

Kose, J. (2003). Incentive Features in CEO compensation in the Banking Industry. Economic Policy Review,9,(1).

Laffont og Matrimont (2001). Theory of Incentives: The Principal Agent Model. Princeton University Press (December 26, 2001).

Levine, R. (1991). Stock Markets, Growth, and Tax Policy. The Journal of Finance, 46(4)

Levine, R. (2005). Finance and Growth: Theory and Evidence. Í P. Aghion, og S.N. Durlauf (Ritstj.), Handbook of Economic Growth,1A, 865-934. Amsterdam: Elsevier.

La Porta et al. (1999). Corporate ownership around the World. The Journal of Finance, 54, 471518.

Magnús Thoroddsen. (2010, júlí) Nokkur orð um dóma Hæstaréttar Íslands um hin gengistryggðu lán. Morgunblaðið.

Morck, R., Strangeland og Yeung, B. (2000). Inherited wealth, corporate control, and economic growth: The Canadian disease. Concentrated Corporate Ownership. National Bureau of Economics Research.

Morck, R., Wolfenzon D, Yeung, B. (2005). Corporate Governance, Economic Entrenchment and Growth. Journal of Economic Literature 43(3), 655-720. 
Prescott, E. (2002). Can Risk Based Insurance Premium control moral hazard? Economic Quarterly, Federal Reserve Bank of Richmond.

Rajan, R., Zingales, L., (2003). The Great Reversals: The Politics of Financial Development in the 20th Century. Journal of Financial Economics 69(1), 5-50.

Rannsóknarnefnd Alpingis. (2010). Aðdragandi og orsakir falls íslensku bankanna 2008 og tengdir atburðir. Reykjavík. 3. bindi.

Thomson. (2009). On Systemically Important Financial Institutions and Progressive Systemic Mitigation. Policy Discussion Paper, 27, Federal Reserve of Cleveland.

Wenger og Kaserer (1998). The German System of Corporate Governance - A Model Which Should Not Be Imitated. Í S.W. Black og M. Moersch (Ritstj.), Competition and Convergence in Financial Markets - The German and Anglo-American Models. Elsevier, North Holland, 41-79.

Williamson, O. (1988). Corporate Finance and Corporate Governance. Journal of Finance, 43(3), 567-591. 